\title{
Writing for Ethical Research: Novice Researchers, Writing, and the Experience of Experiential Narrative
}

\author{
William Edgar Boyd ${ }^{1}$, Sharon Parry ${ }^{2}$, Nici Burger ${ }^{2}$, Jo Kelly ${ }^{2}$, \\ Wendy Boyd ${ }^{2}$, Jubilee Smith ${ }^{2}$ \\ ${ }^{1}$ School of Environment, Science and Engineering, Southern Cross University, Lismore, Australia \\ ${ }^{2}$ School of Education, Southern Cross University, Lismore, Australia \\ Email: william.boyd@scu.edu.au
}

Received October $17^{\text {th }}, 2103$; revised November $17^{\text {th }}, 2013$; accepted November $24^{\text {th }}, 2013$

\begin{abstract}
Copyright (c) 2013 William Edgar Boyd et al. This is an open access article distributed under the Creative Commons Attribution License, which permits unrestricted use, distribution, and reproduction in any medium, provided the original work is properly cited. In accordance of the Creative Commons Attribution License all Copyrights (C) 2013 are reserved for SCIRP and the owner of the intellectual property William Edgar Boyd et al. All Copyright (c) 2013 are guarded by law and by SCIRP as a guardian.
\end{abstract}

\begin{abstract}
The objective of this paper is to better understand how to bring the experience of applying for research ethics approval closer to the practice of research planning. The hypothesis is that, while experienced scholars understand the ethics writing process, early career scholars find that understanding is harder. We adopt experiential narrative methodology to explore individual understandings of the ethics writing process as case studies providing insight into relationships between academic and institutional process. We adopt this approach since experiential narrative allows academics to explore social processes while providing professional development. Building narratives of the experience of applying for research ethics approval, we present six personal accounts from the perspectives of the research ethics committee chair, a senior supervising academic, two early career academics and two doctoral candidates. The paper describes our experience through individual and collective experiential narratives, engaging the narratives of scholarship, intellectual context, participant and power relationships, and professional growth. Extending a previous argument that deeper engagement with ethical curricula will transform students, we demonstrate the effect of deeper engagement upon early career scholars, and demonstrate that the bureaucratic writing embedded in the research ethics proposal can be harnessed to mentor both early and later career writing and scholarly development.
\end{abstract}

Keywords: Ethical Autoethnography; Experiential Narrative; Reflective Scholarly Writing; Transdisciplinary Writing Structures; Research Ethics

\section{Prelude}

... believing in narrative, we must also believe that the story is not finished, that there are other possibilities, and that other voices will enrich and expand it. [Clark \& Rossiter, 2008: 69]

Here is a story: In 2002, Heifetz and Linsky wrote that professional reflection was likened to "going to the balcony from the dance floor". They played with the notion of stepping out of the dance, sitting above the thrall, watching the patterns of the dance from outside, giving the writer an outsider's different perception of behaviour and action. The dance acquires new meaning to the experience of dance: new patterns, new relationships, and new art, which are seen through other lenses. The trick, as it seems, is to find the viewpoint that provides new perspectives, the balcony from which to watch.

Searby and Tripses (2011) took that metaphor-in terms of their own personal writing spaces, away from the office and classroom - to craft a tightly structured reflective examination on their roles as mentors and teachers of mentoring in educational settings. Whilst drawing on a range of scholarly critical and analytical techniques to order their thinking, their core idea seems to be to the need to find a new position from which to reflect. Both realised, reflecting as outsiders to their own prac- tice, that their teaching had grown stale. An implication of Heifetz and Linsky's metaphor is that reflection within the very place of stale teaching was not logical: there needed to be a change in ontological geography. Searby and Tripses' stories started simultaneously prior to, and at the point of, their geographic shift.

We now have a new perspective on our work, and specific goals that will guide our efforts in the next year. Our hopes are high. The best is yet to come. [Searby \& Tripses, 2011: 8]

This paper is another story about reflecting on our practice to create a new narrative, which we expect to evolve and grow. It began as a reflection on the dance of learning between doctoral candidates, supervisors and the chair of an ethics committee. There could hardly be more different stakeholders, yet their stakes in the outcome of ethics approval from the university's human research ethics committee were identical.

There exists a body of literature documenting the nature of academic disciplines (Becher, 1989; Becher \& Trowler, 2002). Whilst different academic disciplines are constrained by their epistemological knowledge bases, they are also constrained by social norms and the epistemological expectations of audiences to whom knowledge is reported (Parry, 2007). Another key 
shift in the nature of knowledge concerns the tidal wave away from traditionally-mode, university-owned knowledge (Mode 1 knowledge) to knowledge made by its users wherever they are in the community (Mode 2) as described by Nowotny et al. (2001). The $21^{\text {st }}$ century's information age gives rise to rapid dynamism in knowledge-making and reporting, bringing with it new ethical boundaries as global research and the knowledge which produces grow increasingly applied trans-disciplinary. No longer can simplistic notions of deductive and inductive logic be rigidly applied. New perspectives on ethical boundaries, and on reflective practice in relation to research, are increasingly important for knowledge to be intellectually and socially reliable and accepted.

\section{Introduction}

While we draw on the scholarship of the field to frame our work, the specific goals, strategies, and interactions that characterize that work are shaped by a deep appreciation for the contexts in which we practise. [Taylor, 2010: 1]

Taylor's observation is a straightforward expression of the need for new approaches to reflecting upon research, in a context where academic disciplines continue to shape knowledge making, albeit drawing upon cross-disciplinary and trans-disciplinary epistemological traditions. The notion of a shifting geography as a locus of professional reflection has, therefore, an appeal worthy, in itself, of considerable scrutiny. The present paper draws on several strands of reflective activity to develop new reflective perspectives and meaning. It focuses on mentoring, by and among the doctoral candidates, novice researchers, supervisors and the chair of the ethics committee at an Australian university. Their reflections come from different experiential viewpoints and levels of types of expertise.

In the present context, the mentors (the ethics committee chair and the supervisor, both with extensive supervisory experience) have previously mentored colleagues in writing-based reflective projects. A situation arose in which the ethics chair and the supervisor were involved in guiding two doctoral candidates and two early career academics with their ethics submissions. That support, while meeting immediate bureaucratic needs, opened an opportunity to work further with individuals, contributing a mentoring role to research planning - either of existing projects or in assisting in the design of new projects. We, the authors, became engaged in a narrative exchange involving discussion, feedback and negotiation to develop sound methodological approaches in tandem with ethics applications -involving practical methods and techniques for making and analysing data. The view from each contributor is different, but we share the value of using others' perspectives to shape our thinking and our research strategies. We could have adopted a hierarchical mentorship Mode l with the ethics chair directing the intellectual enterprise. However, sharing the aim of a successful research strategy, our approach mirrored Searby and Tripses' experience that there is some value in finding another place from which to view the research design: perhaps not a balcony, but in standing aside from our own ontological stances to take new perspectives into account. The two mentors, from science and public policy backgrounds respectively, guided the candidates and early career academics from within their own specialist disciplinary positions, with the ethics chair being deferred to frequently to clarify ethical considerations and to advise on risk reduction and appropriate sourcing of data.
The present narratives begin with the dance between stakeholders in gaining ethics approval to undertake research on people, and at times, with vulnerable people or with children. The dance is the negotiation of different frames of reference for each of the stakeholders, wherein disciplinary, organisational and ethical beliefs and assumptions constrain and are constrained by the individual stakeholders' frames of reference, as first described by Becher for academic disciplines (1989). The common thread is the field of knowledge, teacher education, wherein the various research projects are transdisciplinary and applied, so are contributions to Mode 2 knowledge (Nowotny et al., 2001). The dance becomes a delicate one, involving cognitive, social and ethical constraints in the conduct and reporting of new knowledge that is individualistic, highly personalised, and which crosses traditional cognitive-and potentially ethical- borders.

\section{Experience, Narrative, and Experiential Narrative}

Simply stated, narrative inquiry uses stories to describe human experience and action. [Radi et al., 2008: 112]

There is a growing acceptance that experiential narrative provides a sound research tool that allows academics to explore social processes and relationships (e.g. Estrella \& Gaventa, 1998; Estrella et al., 2000). Importantly, it also provides empowering professional development options (Cloke, 1994). Using experiential narrative, one of the mentors has both explored his own professional development (e.g. Boyd, 2011) and mentored early career academics seeking to engage research schoollarship more fully. In both situations, the work has also contributed to the scholarship of teaching and learning, providing new discipline-specific knowledge (e.g. Boyd et al., 2010, 2012; Boyd \& Horta, 2011; Boyd \& Newton, 2011). The other mentor is well experienced in teaching and learning in higher education, and has studied the nature of supervisory relationships (Parry, 2007) and the changing nature of knowledge (Becher \& Parry, 2005).

Academics and scholars write. Writing is important. It contributes to how we conceptualise our intellectual develop-ment (Lea \& Stierer, 2009). The primary, and often institutionally privileged, focus is on academics as writers for scholarly publication and for reflective professional development. However, in neither case is the writing itself viewed or valued as academic and professional practice in its own right (Lea \& Stierer, 2009: 420); it is a usually just a mode of reportage. The present study emerges from the ethical and intellectual value that even those academics who publish little, or who do not write reflectively to any great extent, have a core of their professional practice-Lea and Stierer's "everyday writing"-that provides a springboard for any mentor to work with in supporting his or her peers or candidates. In drawing on this practice, the present study explicitly links pragmatic experience and narrative with a negotiated, broadly interpreted theoretical tradition. The present study harnesses the research team members' personal reflective narratives about being mentored to learn the ethics and crossdisciplinary conventions they must meet in developing their ethics applications. They thus re-enact Clark and Rossiter's (2008: 64) "language-ing” of experience: "Narrative learning is constructivist in character, but the construction of the narrative is necessary to make the experience accessible (that is, to language it), and how it is constructed determines what meaning it 
has for the person". The "language-ing" of the personal narratives is highly consistent with auto-ethnography (Denzin \& Lin-coln, 2000). It also sits within the well accepted, global overtaking of the hierarchical research tradition of Mode 1 thinking, within the parameters of socially reliable and ethically sound knowledge (e.g. Delanty, 2001). There is, therefore an ontological basis for understanding experiential narrative as both a process and an outcome (Ellis et al., 2011).

In practical terms, the connection between experience and narrative may happen in various ways, through, for example, the constructivist lens learning within the reflection (see, for example, Ellis et al., 2011), the situated learning theorist's learning as a socio-semiotic construct (after Vygotsky, 1935), or the narrative theorist's narrative giving meaning to experience (Clark \& Rossiter, 2008). It is important that, however the connection between experience and narrative works, the process is creative, in the sense that it helps to make sense out of complexity, as Jackson (2005) would argue. It provides, as Colne \& Boone (2008: 7) advance, opportunity for people to "reconstruct... the meaning of events in their lives, ... [to] interpret their environment in new ways, and construct... visions of possible futures based on this curricular experience”, and therefore to purposively learn. What the authors first did to discuss those who were the mentors share in their approach to mentoring. This is necessarily threaded throughout our argument and findings. Then, without discussing our approach in explicit terms with the other authors (the mentees), the others were invited to provide a written piece on their experience of being mentored through the ethics application process.

Importantly, candidates' reconstructions may be seen as a collaborative learning endeavour between researchers as narrators, without a hierarchical power differential where meaning by the more qualified is privileged over those whose qualifications and experience are yet developing. Such a framework for reporting and reconstructing personal narratives, according to Colne and deBeyer (2009: 45), exerts a greater power: "during the moments of encounter with a story we are "colonized" by narrative worlds that determine who we are to be for the duration of the experience”.

\section{The Study}

Reflective practice provides... mental time and space to consider what [the academic has] been doing, value it, place it into context and make mature decisions about what to do next. [Bradford, 2000: 44]

In practical terms, this study adopts the experiential narrative stance to document the experiences that two experienced authors have adopted in their different roles as academic mentors, guides and supervisors. It also provides the perspectives of the research candidates being mentored, or supervised, and it concerns their iterative, developmental writing of a human research ethics proposal. One of the supervisors, as the chair of the University's research ethics committee, developed a narrative style for the ethical "training" that must be provided to applicants for nationally approved ethics applications. The other, as an experienced supervisor, who likewise uses narrative reflectively by way of providing continuous feedback and clarification on candidates' writing drafts, by, according to one of the candidates, "taking each draft afresh and giving feedback so that the writing is iteratively improved". Building a narrative of research experience as a framework for contributing to profes- sional development amongst colleagues-in other words, talking stories of research practice, rather than training through didactic instruction - the authors seek to mediate the experience of others writing research ethics applications as a narrative of research embedded in the principles of (in this case, Australia's) primary guiding research ethics documents (Anon, 2004, 2007). Elsewhere, the processes of conceptualising research and writing proposals has been described as needing to be able demonstrate the researcher's immersion in the cognitive and social conventions of the discipline (Becher, 1989; Becher \& Parry, 2005), and Parry has linked this with Bourdieu's notion of cultural capital in academic specialisms. Boyd (2009), in the same vein as Delanty (2001), has advanced this notion to accommodate empathetic considerations of ethical conduct of research, not only accounting for technical competence in the practice of research, but also to account for how this plays out within disciplinary and trans-disciplinary writing structures, conventions and constraints. The mentors attempt to build upon the strengths in the writing to question how evidence might be more ethically obtained and reported. In this way we have engaged in a two-way reflective learning experience for all participants, even though much of the knowledge generated is initiated by the novices amongst us. We agree that we are all equal contributors to the reflective process, consistent with Delanty's (2001) notion of reliable knowledge, where knowledge is made a within and by the community, thus contributing to citizenship ideals.

The "ethics" writing, where we are engaged mindfully with contextual spheres of thought, therefore expands the space of scholarship through experiential and reflective narrative. In the present study, a previous argument by Boyd et al. (2008) - that deeper engagement with ethical considerations is emancipatory and empowering, takes into account ethical decision-making and evolving personal, ethical and cognitive growth to bring about deeper engagement with "ethics" writing and the robustness of the research enterprise on disciplinary, ethical, personal and community levels.

Because the approach is highly intuitive and involves tacit knowledge gained from intuitive engagement with colleagues' narratives, it remains untested, other than by observing the subsequent success of applicants in their research ethics submissions. This present study was set up to reflect on this negotiated, guided approach to developing research proposals and ethics applications as they develop cognitively, ethically and practically in a deep engagement with theoretical traditions and the conventional research methods of particular specialisms. The study uses an experiential narrative lens through which to view our various research perspectives and experiences of writing for research ethics approval under the constraints of ethical guidelines and disciplinary know-how. The aim is also to document and illuminate key processes in our professional and intellectual growth, and especially in advancing our individual capacity to harness ethical scholarly approaches in a time the knowledge terrain is rapidly changing.

The study is methodologically grounded in ideas rehearsed above, based on the recognition that self-reflection and biographical scholarly writing have long academic histories as critical social analysis (Chamberlayne et al., 2000). Social constructivist, postmodern and postcolonial theories all allow narratives to be examined as social process (Marcus 1998; Roberts, 2002; Silverman, 1997). Engaging the study within a critical reflective mode, we adopt peer- and self-review that marries the 
practical application of experiential learning and reflective observation (Fry et al., 2003) with the strengths of reflectionin-action and reflection-on-action as described by Schön (1983). Practically, we harness our critical reflection through narrative writing, throught both unstructured individual, context-specific discussions, and individual writing.

Our process of writing-as-discovery echoes the use of biographical narrative in the social sciences in critically engaging with academic processes (Chamberlayne et al., 2000; Clandinin \& Connelly, 2000; Geertz, 2000). Trahar (2009: 5) notes that researchers using narrative cannot know the stories that are meaningful for participants, and need to trust participants to tell stories that are meaningful for themselves. We note Trahar's (2009) observation that the traditional anonymising of participants renders the narrative-tellers invisible. We overcome that concern by co-participating as co-researchers and co-authors, contributing individually and collectively to the narrative, reducing the risk, as identified by Radi et al. (2008), of privileging any one contribution over another.

\section{The Reflective Narratives}

We construct a narrative of what was at first strange now becoming familiar, of values and ways of being in the world slowly making sense to us who are outsiders to the culture. It's a continuous process, of course; narratives like this are always tentative and evolving, which is appropriate because learning itself has no endpoint. But this narrative construction, this storying of our growing understanding of something, is how we make our learning visible to ourselves. [Clarke \& Rossiter, 2008: 66]

The writing of a research ethics application is closely related to, but different from, the writing of a research proposal. This dichotomy presents a fundamental challenge to early career academics and doctoral candidates, whose due diligence in writing the proposal leads to dismay and embarrassment when their application is strongly criticised by the ethics review committee. Research proposals are typically written under the usual headings of title; literature review; problem definition; aims; objectives; methods; timing; special features; references (Boyd, 2009). However, a research ethics proposal needs to take this as a foundation, and present it as evidence of the research being able to meet the principles of ethical research, and using precise logical flow as outlined by Swales and Najjar (1987). In Australia, for human research, researchers must reflect on the principles of Research Merit and Integrity, Justice, Beneficence, and Respect, and addressing issues of risk and its balance against significance of the research and management of risk (Anon, 2007). In addressing these principles, the researcher often finds that modification to research design and proposed method is necessary. The writing of the research ethics proposal, therefore, often acts as a trigger for early reflection-reflection even before the research has really started-by the researcher on their research practice, and by the supervisor on their professionalism and expertise invested in the proposal.

It is at this point of intersection that this study begins in an Australian university setting. There are disciplinary, trans-disciplinary and organisational constraints on the nature of the writing register for applicants to master for an ethics application. None of these conventions are explicit, and they are tacitly learned (Parry, 2007). In the narrative dance between the chair and the applicant, cues are being parlayed and the writer learns to negotiate an acceptable writing outcome in a kind of intellectual dance. The dance is finely nuanced, as it also involves the applicant affectively; they are baring their professional competence, both intellectually and in terms of their moral compass. Boyd (2009) notes that experienced researchers are already what Miller and Parlett (1976) would call "cue conscious", when it comes to writing ethics applications, but novices need to be "cue-seeking". Discussion about the appropriate register and conventions can begin with training sessions that lead to the negotiated development of the application. However, those discussions may begin upon submission to the committee, so that a delicate dance ensues where the applicant learns the conventions and ethical boundaries in a manner that pays due positive regard to each party in recognition of the dynamism of the knowledge base and, therefore, of its conventions for making and reporting knowledge. However, there could be a very different scenario were the gatekeepers (ethics committee chair, supervisors, senior colleagues) to exercise their power differential to control how the knowledge will be made and to wrest control of its ethical compass.

Textboxes 1-6 present our individual narratives reflecting on our engagement with the processes of submitting applications for ethics approval. The voices are different, reflecting the different reference points of each individual, while giving expression to our individual experiences.

\section{Where Do Our Narratives Take Us?}

The moral impact of the encounter came about through a specific interaction between the narrative world offered by a speaker and the existing imaginative repertoire of a listener. [Colne 2007: 11]

Colne's (2007: 12) examination of the moral qualities of experiential narrative considered that the "ethos of a narrative... potentially has its greatest impact during the reader/listener's encounter with it, because it is at this moment that the narrative patterns desire and call forth certain emotions [allowing] the experiencer momentarily to live a different life and take on new identities". A test for such a claim lies in our study. There are two axes of the encounter: the encounter with the narration by the narrator him or herself, and its encounter by the others. It is the potential for the reader/listener to "momentarily to live a different life and take on new identities" that potentially provides the opportunity for professional development. In our case, that professional development takes the form of, for some of us, writing ethics applications better (on the surface) and planning research better; for others, it takes the form of being better able to provide meaningful and effective mentoring support. Above, we commented on using the narrative of research experience as a frame to engaging the ethics application process, and we argued that, in doing so, we seek to engage the narratives of scholarship, intellectual context, participant and power relationships, as well as personal/professional growth.

This engagement has expressed itself in several ways throughout our reflective narratives. In Sharon's deliberations of the role of supervisor and mentor, simultaneously guiding candidates through both the development of a research project and the requirements of ethics approval, demonstrates the strength and relevance of Mode 2 knowledge in these forms of professional development (Textbox 5). However, she is also acutely aware of Mode 1 context, and helps us understand that 
Textbox 1.

Nici: My experience in writing and developing research through the ethics application process.

\begin{tabular}{|c|}
\hline 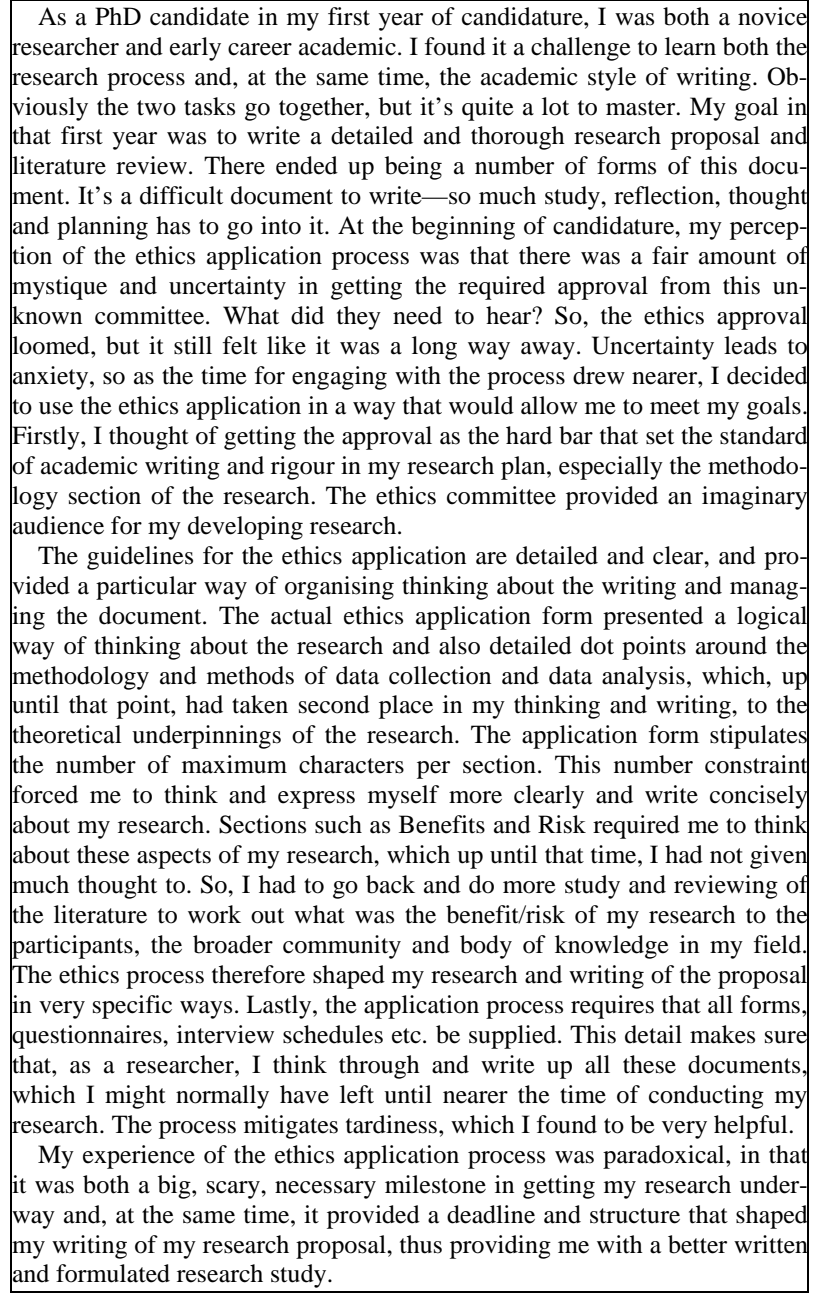 \\
\hline
\end{tabular}

there is an essential relationship between the formality of institutional knowledge and bureaucratic systems and the potentially organic nature of scholarly knowledge development. Nici (Textbox 1) commented on the paradoxical nature of the experience- - it was both a big, scary, necessary milestone in getting my research underway and ... a deadline and structure that shaped my writing of my research proposal, thus providing me with a better written and formulated research study" -while Wendy (Textbox 2) observed that "the process of writing an ethics application... is valuable for refining the actual research questions, the aim of the research, the methodology to be employed, and for addressing the "So what?" question... [ in which] the writing becomes more refined and deepens one's understanding and learning about the research as each category is addressed in the application". Jo's dance with potentially dwindling motivation was tempered as she re-wrote her ethics application and became aware that "like my $\mathrm{PhD}$ metaphor of the Labyrinth, I get close and then further away, but always, always moving towards my goal” (Textbox 3). Jubilee's metaphor of the cake stands on its own terms (Textbox 4). Bill, while on the other side of the equation, reflected on his intellectual engagement- the practical implications of adopting
Textbox 2.

Wendy: The role of reflective narrative writing as a mentoring process, and its intersection with writing for, and guidance on, ethics submission.

The process of writing an ethics application for the conduct of research is valuable for refining the actual research questions, the aim of the research, the methodology to be employed, and for addressing the "So what?" question-that is, an explanation as to why this research is beneficial, and to whom. The writing becomes more refined and deepens one's understanding and learning about the research as each category is addressed in the application. This process calls for being succinct while concurrently conceptualising and thematising the main constructs of the research.

Recently, I was writing an ethics application to conduct research to interview colleagues about the benefit and disadvantages of group presentation assessment tasks. The following week, I was due to present this research proposal to colleagues. I found that the process of writing the ethics proposal enabled me to identify, conceptualise and articulate the rationale and purpose of the research, and explain why this research was important. The task assisted me greatly to prepare my presentation about the research; it was similar to a guide. During the writing of the ethics proposal, I had constructed the key themes of the research. Therefore, as I developed my presentation, it was easy to move from the ethics application to the Powerpoint presentation. The Powerpoint slides I developed to explain the research proposal were very clear according to feedback from colleagues. This I believe was because of the key questions/categories from the ethics application which provided a valuable framework for the conduct of the research and my presentation.

The process of writing and responding to the key questions in the ethics application was indeed like a mentor for me, albeit an e-mentor as the ethics application was completed over the internet. It is interesting that one could consider the process of writing an ethics application to be a process of guided learning by a mentor. For me ethics applications were considered a necessary task to complete prior to gathering the data, and up to that point I had not viewed it as a process of learning and refinement of research. It was a valuable task that led me, the researcher, to a different level of understanding about my intended research, and forced me to reflect on my research goals.

The "So what?" task was the most challenging. Why is this research of benefit? Who will it benefit? How do I know this? I was forced to make sense and meaning of this research proposal. While I knew what I wanted to achieve, it was the conceptualising, the thematising, making links between ideas and past literature that led me to review, reflect and re-write until had refined the project to a clear achievable research proposal.

a constructivist approach-with the pragmatics of the task his university has charged him with (Textbox 6).

In more immediate ways, the reflections represent a maturing of perspective amongst all the authors. Previously we suggested that, in practical terms, the path through which this occurs is probably irrelevant-we are interested in the pragmatic outcomes-it seems likely that the three modes described by Clark and Rossiter (2008) are being engaged here. All the reflective narratives talk, to a greater or lesser extent, of the specific learning gained simply by articulating practice through the text; while this may be expected for the candidates and early career academics, it comes through even the seemingly well advanced views of the more experienced authors, as in, for example, Bill's closing statement of becoming a learner through the mentoring process (Textbox 6). On the other hand, learning as a socio-semiotic construct seems less immediate although, perhaps as may be expected, the more experienced authors consider this. However, in choosing her particular form of narrative, Jo is attempting this approach (Textbox 3); Jubilee's metaphor of the cake hints at a nascent semiotic engagement (Textbox 4). Ultimately, we suppose, we are seeking expression of the narrative theorist's expectation of the narrative giving meaning to experience.

Whatever the path, it appears that all the reflective writings add, by each individual author's admission, to both our indi- 
Textbox 3.

Jo: The hero's journey...

Prologue Context is everything. I started this PhD after briefly working in the public school system as a Casual School Counsellor. I am not a qualified school counsellor but have the maturity, skills and knowledge to be used in a system that is desperately short of counsellors. With a honours degree in Education and a Masters Degree in Mental Health (Art Therapy), the public education system appears not to officially recognise the latter qualification. This is evidenced by the policy for the Education Department in this area. Only qualified school counsellors can access confidential files of students. I found myself in an ethically questionable position of writing confidential notes, including artwork done with the students in counselling sessions, that I could not have access to, once they were confidentially filed. Ironically, it was through this problematic ethical issue, I decided to further my studies.

Chapter 1 When I embarked on my PhD, I received some useful suggestions that have remained with me, "Leave your ego at the door" and "Writing is an iterative process". Both of these little gems have stood me in good stead. I knew when I started that I would have to navigate the whole ethics process and took advice early on from the Head of the Ethics Committee. At the time the meeting was set up, I had not really defined my question. The very act of discussing elements of an ethics application helped me to refine in writing what I was trying to do. So too does doing artwork. Writing ethics applications is more than just filling in forms. It is similar to trying to find both the acceptable language key, as well as thinking hypothetically through the process of one's own investigation in a very practical way. Articulating this in academic language takes practice, again and again. In using the past experience and knowledge of others who have done this many times before, the mentoring discussions reflected back to me both the do-able and less do-able parts of my research. I believe it is this mentoring process that has helped improve and develop my writing to the extent that $\mathrm{I}$ am now sure I can eventually write a thesis in a way I was not at all sure of at the beginning of this journey.

Chapter 2 When my own Ethical Full Review was queried on the grounds of role separation issues between therapist and researcher with students in the same school, I put this to one of the school students I was currently counselling. She emphatically disagreed with the decision of the Human Research Ethics Committee! Out of the mouths of babes. It was suggested by the Committee that I look to other students with whom to conduct my investigation. The trouble was, this would mean not only this ethics process, but also other ethics forms and to interview students with whom I had no relationship with whatsoever. I was aware that my motivation was dwindling. Affective factors influence the whole process in my view. In the early stages of my journey, it would not have taken much criticism to have gone home and taken up knitting. The positive and encouraging mentoring support I have received has meant that I have never once thought to go home ...

Chapter 3 My ethical hiccup meant my determination was fired up to find out exactly what was needed to enable me to jump those hurdles, for I needed to get my ethical approval through before I could progress any further. Returning to my mentors and in rethinking the process and practicalities, I think a compromise has been reached. I know what I need to do in order to meet my goals. To this extent, while my investigation is very close and of personal importance to me, I have to let go and "leave my ego at the door", by taking on any advice about my application. This was less about my way of writing perhaps, and more about procedures.

Epilogue I think my writing is flowery and descriptive. Better used to a creative writing course maybe than a $\mathrm{PhD}$, maybe. I know I can use the written language to articulate my intentions, but this genre of writing is not only about drafting and redrafting by the writer, it is about others having both verbal and written input. I am getting used to my writing being critiqued by others. For me it is about crafting, creating and improving, by practising and practising. As I write this with a more streamlined ethics application and awaiting a decision, I know through this process, that like my $\mathrm{PhD}$ metaphor of the Labyrinth, I get close and then further away, but always, always moving towards my goal.

This image is about the interweave of others' contributions to my work. Green represents knowledge and growth.

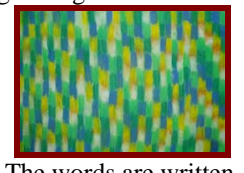

The words are written,

Again, revised many times over

I communicate.
Textbox 4.

Jubilee: Reflections on the ethics writing process.

I am definitely a person who needs to be engaged with other people in order to further my ideas. As a student, teacher and academic I thrive in situations working with other people. However, when it comes to writing, I do not feel confident or capable-my self-efficacy regarding writing is very low. I believe there are a number of reasons for this-some are related to my lack of experience in my education degrees, and others related to my work as a "teaching" academic. Over a number of years as an academic I have not engaged in what may be termed research based or "real academic" writing, and as such I feel unsure of my own ability to write about ideas beyond my own teaching.

So, what would I contribute to the ethics writing process if I was unsure of my own skills and understanding and ability as writer? Would I be too overwhelmed by my lack of real experience with writing to be able to contribute in a meaningful way? Would my colleagues be supportive or condescending about my lack of experience?

As part of the process I was initially unsure of my contribution and, in all honesty, this was not my area of expertise. However, my initial feelings whether I belonged in the group were shifted quickly as the other writers (the key researchers and writers-my colleagues) made me feel supported and listened to, even if I was the least experienced in the group.

As the process of writing and refinement took pace, I felt as if I was an observer in many ways. In the past this may have made me ask whether I was able to contribute at all. As I read what others had written and provided feedback about other people's writing I realised an important lesson about writing and about research. I saw, for me, that the reflection and consideration of ideas cannot be neglected, and that mentoring and collegiality can serve as an important part of making sure that the purpose of the writing stays on track. However, I think, most importantly for me, I could see my role as part of the writing/ research team.

This has lead me to consider that, when research is being lead by a team, as opposed to an individual, all of the voices, like all of the ingredients in a cake play a role, and it is not until the process is complete that the role of each ingredient becomes evident. Although I did not write directly for the ethics application and the ideas were not "mine", I still felt ownership in the process - partly due to the mentoring of my colleagues and, I think, partly because when the process is allowed to be fluid and people are allowed to move in and out of doing the writing and reflecting, the writing it is strengthened.

I am by no means completely confident in my own ability to write after this process, yet I am now clearer about the expectations, the importance of reflection and the value of each person in a team approach. I have heard it said that there are no good answers, only good questions, perhaps the process for me is about learning to ask the questions, and to be confident that they are important enough to end up in the cake!

vidual and collective understanding of what happens while writing an ethics application: the interactions between the layers of complexities, of conceptualising, responding to imaginary and imagined (and real) audiences-comment on the role of audience, real or imagined, repeats itself throughout the reflections - and the demonstration of personal and professional growth as an academic, researcher and scholar. Furthermore, the iterative process that we have engaged in-both the iteration between research planning and ethics application writing, and of the reflective narrative format of collaborative discovery by writing - in itself provides possibilities for ongoing reflection. A common theme is the tension between the bureaucracy of the ethics form and its very different relative, the research proposal writing - the proposal needs to be developed in order to enable a cogent application - and the release of that tension through a mentoring, supportive and trusting relationship which allowed the research planning, writing and ethical priorities to develop in tandem. This working in tandem served two jobs: one of articulating the investigation to an audience as well as assisting with thinking through just how the investigation would go step by step.

The concept of liminality keeps recurring. The candidates, in 
Textbox 5.

Sharon's reflection on mentoring ethics application writers.

My background is one of research into epistemology, and in particular to disciplinary, and trans-disciplinary conventions arising from the nature of the knowledge base. I understand how these conventions, first articulated by Becher (1989), and which further articulated through empirical research, are for the most part, not explicit: they have to be tacitly learned. The conventions are tacit cues to writing in a manner that the audience will identify with and understand. In the case of ethics applications, there is also the overlay of the administrative traditions of the Ethics Committee and the constraints of national legislative requirements.

As a supervisor or mentor, I have found that it is critically important for the applicant to get the research aim and central questions set in order to arrive at an ontological position that instructs the nature and shape of the methodology, methods and techniques to be used. My approach is to work iteratively with applicants until they are beginning to have to make methodological and, therefore, ethical decisions about data collection and reporting. At that stage, which is sometimes quite early, I suggest that the proposal be iteratively drafted in tandem with the application for ethics approval. My contribution to the reflective narrative process is simple. Every iteration is one I comment on afresh, bring no bias or judgement from previous iterations or referring to previous feedback. The intention is to give equal positive regard to the applicant, until I think the various constraints have been met. We check with the Chair when we are not sure. It is not an altruistic approach; rather, the applicant and I are learning from each other and building our intellectual capital as we progress, each with our own different intellectual agendas. What is mutual, however, is our moral compass, which must be shared if there is to be equal positive regard.

The negative feedback Jo received on her application concerned including young people with whom she has worked professionally. I was not aware that researcher cannot research individuals (in this case young people) with whom they interact professionally and as the responsible professional. In the scholarship of teaching in higher education, this is the only kind of data the researcher works with! I have learned that the boundaries of ethical research are sometimes contradictory, and that the aim to behave ethically in research is a different aim from behaving to reduce risk to participants, and in particular, to avoid potential legal risk. At the same time, there is a delicate balance between the Ethics Committee's leader having a positive and encouraging approach, rather than a highly defensive one. In Jo's case, this made a world of difference.

As a researcher and a gatekeeper in many research enterprises, I watch with great interest how Mode 2 knowledge developments test our individual and collective ethical perspectives, and I observe with a wry lens, how ethical considerations emerge and play out as knowledge production is increasingly achieved by novices, many of whom are not qualified (as in the collective argument set out earlier). It is an inevitable outcome of the information age and knowledge production in the 21st century.

My final thought comes from a colleague here in the university, relating to research in the social sciences. She tells her doctoral candidates to "leave your ego at the door". The dynamism of the information age base brings with it increasing uncertainty as knowledge explodes and bursts through traditional barriers and conventions. We cannot rely upon Mode 1 conventional knowledge hierarchies: we must negotiate the production of socially reliable knowledge with our communities. It is my belief that, regardless of our status as researchers or our position as gatekeepers in the production of knowledge, the need for negotiating the production of knowledge means we all must we must all leave our egos at the door.

particular, find themselves in a liminal space within the academic system, which can be anxiety making, challenging and yet exciting, particularly and especially when one feels that others want you to succeed. Both Wendy's and Jubilee's reflections (Textboxes 2 \& 4), however, suggest that such liminality is not unique to students. It may be argued, of course, that the supervisors and ethics chair are equally searching for their liminal space: it is likely that these spaces do not align with ease, although there may be potential for them to align through the process of mentored writing. As Jo commented, in an email to the group, towards the end of our writing process:

So, getting a written proposal is a hurdle, the ethics is another and candidature another. Through that process there is
Textbox 6.

Bill's reflection: Now here's a funny thing...

Now here's a funny thing. Here's me, an academic brought up in the tra dition of the academy, a scholar by profession and culture, having drifted from an original training in the physical sciences through to the social and cultural sciences-I use the word deliberately, in the sense of scientianow advocating a central role for reflective narrative and the act of writing as a mode of enquiry. Narrative and writing? Where is the science in that? Writing, yes, my scientific colleagues use writing as reportage, but as a mode of enquiry? And narrative, well that's just for the arty people...

In the mid-nineties, I discovered books on the new humanities, and experienced a sense of liberation from the so-called objective truth! I must have been ripe for an intellectual re-awakening. I realise, now, of course, that my early days of social campaigning, first years in Australia as a Scotsman teaching Aboriginal geography, early palaeobotanical interests in prehistoric magic and medicine rather than ecology, all reflect an nascent interest in the social nature of knowledge. Discovering social constructivism allowed me to redefine my understandings of knowledge, and create a meaningful frame around my research, teaching and service-I have called it elsewhere, "a frame to hang clouds on". At the end of the day, as I remind my environmental management colleagues, it is really only the people that matter.

So, when it came to taking up the chair of the ethics committees, does it seem unreasonable that I should adopt a social and facilitative, rather than bureaucratic or compliance ethos? It seemed, at the time, the only reasonable approach: rather crudely, we could bludgeon researchers into adhering to ethical principles-hardly an ethical act in itself-or we could hold hands. My inclination was towards the ethics process not as an obstacle designed to hinder the researcher's right to research, but as an integral constructive part of planning and developing ethically sound, and hence intellectually sound, research. Indeed, I had previously published an article advocating integration of ethics throughout the curriculum, in order to create what I called "an empowered graduate with well-developed capacity for ethical decision-making and evolving personal attributes”.

What does this mean in practice? It means that we need to re-assess roles and responsibilities, especially with regards to power and authority. This is a challenge, I acknowledge, to traditional academic hierarchical structures. Building on my social constructivist inclinations - that the validity of a matter lies in its existence rather than any singular supposedly objective truth or correctness-I am comfortable valuing each person's individual experience, views or skills in their own right. In other words, I can suspend my own sense of authority or differential power: I seek to treat everyone with equity. This does not mean that I deny my own expertise and authority in some matters, and indeed I think all of us should act upon our expertise where appropriate. However, it does allow a sense of acceptance of others' humanity: it privileges the other over the self. This would be expressed in some social settings as respect being earned not assumed. In a practical sense, it allows me to apply my knowledge, expertise and experience, not as an imposition, but as a partnership with those I work with. That's the ideal, anyway!

And in really practical, day-to-day terms, my approach demands acceptance of individuality and personality, negotiation of working relationships, awareness of other's skills and personalities. It is not a passive equity, indeed. And there is always a risk of tension: for some, the authoritarian hierarchy is important, and if I am true to my sense of relationship, I need to respect that, and, ironically, work within it, playing the senior hierarchical part. But where people are open to being treated as equals - equals with different skills rather than levels within the organisational pecking orderthen the scope for advancing in a truly human, civilised way is huge. And the obvious action from this, for me, is to offer myself as a mentor.

However, I have found an interesting spin off from this approach, a validation of the current higher education mantra of "life long learning". As a mentor trying to work within a model of social equity, I become a learner. Suspending hierarchical position opens the door to accepting learning with my colleagues, regardless of their position in the scheme of things. Learning from ones mentees is, I think, a mark of respect. And every human being responds well to respect. If I can add to someone's sense of selfrespect, I will consider my job well done.

I will admit that I am an idealist in all of this, something of a dreamer, perhaps, but happy to keep chipping away at the edifice of authority. Somewhere, many years ago, I came across some lines from T.S. Elliot, which seem, in ways only poetry can, to capture my conception of where the realities lie: Between the idea/And the reality/Between the motion/And the act/Falls the shadow. 
absorption to some extent, of our mentors language and styles. None of this can successfully happen without the context of a primarily supportive relationship. Writing is not just about conversation if we take that in a literal sense and not just about words. The very act of writing has an affective component. If one feels confident about one's writing, then one is more likely to develop as a writer and researcher. There is an acceptable milieu of writing and an academic language style. If one travels too far from that, then the writing becomes controversial and unacceptable. Novice researchers are being inducted into the culture of academia in this process, with its attendant rituals and a range of sensibilities constraining how one reports what kind of knowledge.

A further theme recurs, the embodied nature of the experience. Jo's notion of a journey places the body of the writer as centre stage, along with her acceptance of letting go, and of leaving the ego at the door, both fully corporeal responses (Textbox 3). Nici's comments on writing-as-exploration echo such embodiment of the process (Textbox 1). Wendy's thoughts on the role of the form itself as mentor are particularly striking: "The process of writing an ethics application was indeed like a mentor for me, albeit an e-mentor ... It is interesting that one could consider the process of writing an ethics application to be a process of guided learning by a mentor" (Textbox 2). To personify the tangible component of the writing came as a surprise to the supervisors, who considered that it was the person of the mentor who was the mentor, not the person of the process.

Embedded in the narratives are shadows of risk. Naturally, such level of reflective engagement may not be risk free. Manathunga et al. (2010: 40), for example, comment on the sharing stories of personal experience as being a "balancing act, a process of choosing what to move from the private to the public, [of] balancing a desire to share against the fear of exposure; balancing voice and silence”. Narratives are purposeful and particular, each being a "reconstruction, particular to the position from which the writer views the world and the questions they ask of it”. The strength of the collaborative writingthe achievement of Bill's desire to respect "individuality and personality, negotiation of working relationships, [and] awareness of other's skills and personalities' (Textbox 6) - is reflected in several of the narratives exposing anxieties (Textboxes 3, 4 \& 5): Jubilee's concerns about self confidence; Jo's anxiety about letting go cherished plans; Sharon's concerns that the "boundaries of ethical research are sometimes contradictory, and that the aim to behave ethically in research is a different aim from behaving to reduce risk to participants, and in particular, to avoid potential legal risk". These in this case, served not to critique the role that ethics approval plays within the institution (Mode 1), but to open space for further reflection (Mode 2).

In effect, finding the reflective narrative, especially in a collaborative and shared writing space, is about finding a voice; the individual voices, and, importantly, the ability for a group of academics to respect and acknowledge the variety of voices, reflects the importance and strength of Clark and Rossiter's (2008: 64) "language-ing" of experience. The success in this case of individuals finding their own voice likewise validates the role of "language-ing" of the personal narratives in such autoethnographic reflections (Denzin \& Lincoln, 2000). Elliott-Johns (2011) recounts a familiar situation, in reflecting on her own writing paralysis as new faculty member but experi- enced teacher, spending more time reading about writing instead of actually writing, Elliott-Johns interprets some of her issues on terms of the effects of external expectations on our writing, how our disciplinary training prepares us for writing in the academy and how we see ourselves as writers. In recognising that "we cannot merely assume that because someone has a teaching background and a Ph.D. that... the requirements for success as a teacher and researcher are going to automatically 'fall into place'...”, she argues the need for professional development, peer support, shared writing, etc. (Elliott-Johns, 2011: 8).

Our reflective study provides evidence for the effectiveness of an institutional point of contact, where such support can be articulated on a regular, predictable and trustworthy basis. Despite the notion that the bureaucratised writing, so typical of the academy, which demands that academics "write [not] to persuade but to impress and gain approval within a hierarchy" (Brett, 1991: 520), and which manifested itself in Elliott-John's "pre-occupation with and ... over-emphasis on 'acceptable' writing for the academy [exerted] a powerful influence over [her] ability to write anything at all in terms of what could be deemed 'scholarship'”, we demonstrate that the very bureaucratic writing embedded in the research ethics proposal can be harnessed to mentor early career-and later career-writing and scholarly development. The success in harnessing of this form of writing revolves, however, on the adoption of alternative forms of writing, the personal, the experiential and the individual languaging of individual responses. These acts of writing deconstruct givens, and open opportunities for exposure of a new understanding of a personal reality (Williams, 2013). They allow reflective writers, in Sullivan's (2010: 67) words, to "bring implicit and tacit understandings to a problem at hand and [allow] these [to] interact with existing systems of knowledge to yield new insight", and thus to be able to value, as part of the experimental inquiry, on serendipity and intuition (Boyd et al., 2012; Dean \& Smith, 2009; van Luyn, 2013). Williams' characterisation of memoir writing can readily be adapted to describe the forms of writing demonstrated to work successfully here:

Writing memoir entails more than researching, recording and constructing ... [t]he act of writing forces a set of critical strategies similar to that of writing a fictional work: there is a problem to be solved, narrative choices to be made, a theory to be tested. [Williams. 2013: 1].

\section{Conclusion}

The story tries to mold me, giving me practice, as it were, in wanting and fearing certain qualities and ignoring all others. ... This tacit colonization then is the basis for the ethical power of narratives, experiential or otherwise. [Colne \& deBeyer, 2009: 45]

This is very much a collaborative narrative inquiry, in the sense of Radi et al. 2008. They suggest a duality of meaning of "narrative": "a story version of the events for the [narrator] and a narrative as a lived experience between the researcher and the [narrator]" (Radi et al., 2008: 112). Importantly, these narratives become a shared narrative: while it has to ensure the narrator's story gets told, that is it is acknowledged as being an authentic telling of the narrator's lived experience, the collaborative process enhances this as a "mutual storytelling and restorying as the research proceeds" (Connelly \& Clandinin, 1990: 
4). In Trahar's terms, we can now think of the experience as one of redefining the "ownership of stories" (2009: 15):

If the story is constructed collaboratively, then who "owns" the story? Has it become a communal story of which we all have ownership? Or, indeed, do any of us have ownership because the story was not my story or their story but became a story through those stories? [emphasis in the original]

The nature of this project was one of mutual storytelling, from the earliest introduction, in a formal setting, of research ethics review requirements, through the writing and submission of ethics applications and ensuring conversations between the applicants and the ethics chair. Final submission, and/or revisions, while probably rarely conceptualised as such, are effectively a shared narrative, written out of the lived experience of the researcher and, where required, the supervisor, iteratively developing the research and replanning it, seeking research ethics approval, and receiving more feedback from the ethics committee, via the Chair, in reviewing and responding to the submission. Indeed, in some cases the collaborative narrative commenced earlier, as the researcher discussed the submission, and indeed the proposed research, prior to writing. Mirroring Radi et al.'s (2008: 112) claim that "we need to tell our own stories as we live our own collaborative researcher/teacher lives”, the researchers' and ethics reviewer's (cum-mentor) stories have become collaborative narratives. The immediate success of this collaboration is, of course, the award of a human research ethics approval number and the permission to conduct the propose research. As we have shown here, there is a longerterm and continuing benefit-also a duality — in the ethics chair, in his various roles as chair, mentor and supervisor, being better able to communicate his or her needs with researcher, and importantly-and often seemingly exclusively in a mentoring relationship - the researcher gaining a deeper understanding of his or her craft and discipline.

As reflective writing and auto-ethnographic writing become more deeply embedded in contemporary higher education and scholarly research, it is important for learners, teachers, academics, scholars and researchers to be able to break down the barriers of inductive logic where one individual "owns" a particular perspective, and to develop systematic ways to develop reflective narratives through a kind of benchmarking of perspectives and expertise, so that ultimately a broader audience can identify with the scholarship, curriculum, syllabus or research closely, and understand its ethical implications from a more panoramic view. This study is a first step towards that goal.

\section{REFERENCES}

Anon. (2004). Australian code of practice for the care and use of animals for scientific purposes. Canberra: National Health and Medical Research Council, Australian Government.

Anon. (2007). National statement on ethical conduct in human research. Canberra: National Health and Medical Research Council, Australian Government.

Becher, T. (1989). Academic tribes and territories. Buckingham: Society for Research into Higher Education and the Open University Press.

Becher, T., \& Parry, S. (2005). The endurance of the disciplines. In I. Bleiklie, \& M. Henkel (Eds)., Governing knowledge: A study of continuity and change in higher education (pp. 133-144). Dordrecht: Springer. http://dx.doi.org/10.1007/1-4020-3504-7_9

Boyd, B. (2009). Developing the research proposal. In S. M. J. Baban
(Ed.), Research: The journey from pondering to publishing (pp. 93120). Kingston: Canoe Press.

Boyd, W. E. (2011). Bridging the gap from skills assessment to problem-based learning: Lessons from the coalface of scholarly engagement with curriculum development. International Journal for the Scholarship of Teaching and Learning, 5, 9.

Boyd, W. E., Healey, R. L., Hardwick, S. W., \& Haigh, M., with contributions from Klein. P., Doran, B., Trafford, J., \& Bradbeer, J. (2008). None of us sets out to hurt people: The ethical geographer and geography curricula in higher education. Journal of Geography in Higher Education, 32, 37-50. http://dx.doi.org/10.1080/03098260701731462

Boyd, W. E., \& Horta, H. (2011). Network ethics in the growing global, multi-dimensional and technological academy: Introduction to papers presented at the 2009 Network Ethics Conference. International Journal of Cyber Ethics in Education, 1, i-v.

Boyd, W. E., \& Newton, D. (2011). Times of change, times of turbulence: Seeking an ethical framework for curriculum development during critical transition in higher education. International Journal of Cyber Ethics in Education, 1, 1-11. http://dx.doi.org/10.4018/ijcee.2011070101

Boyd, W. E., O’Reilly, M., Bucher, D., Fisher, K., Morton, A., Harrison, P.L., Nuske, E. Coyle, R., \& Rendall, K. (2010). Activating the Teaching-Research Nexus in smaller universities: Case studies highlighting diversity of practice. Journal of University Teaching and Learning Practice, 7, 19.

Boyd, W. E., O’Reilly, M., Rendall, R., Rowe, S., Wilson, E., Dimmock, K., Boyd, W., Nuske, E., Edelheim, J., Bucher, D., \& Fisher, K. (2012). Friday is my research day: Chance, time and desire in the search for the teaching-research nexus in the life of a university teacher. Journal of University Teaching \& Learning Practice, 9, 19.

Bradford, M. (2000). Improving students' team and personal skills. Cheltenham: Geography Discipline Network.

Brett, J. (1991). The bureaucratization of writing: Why so few academics are public intellectuals? Meanjin, 50, 513-522.

Chamberlayne, P., Bornat, J., \& Wengraf, T. (2000). The turn to biographical method in social science. London: Routledge. http://dx.doi.org/10.4324/9780203466049

Clandinin, D. J., \& Connelly, F. M. (2000). Narrative inquiry: Experience and story in qualitative research. San Francisco: Jossey-Bass.

Clark, M. C., \& Rossiter, M. (2008). Narrative learning in adulthood. New Directions for Adult and Continuing Education, 119, 61-70. http://dx.doi.org/10.1002/ace.306

Cloke, P. (1994). (En) culturing political geography: A life in the day of a rural geographer. In P. Cloke, M. Doel, D. Matless, M. Phillips and N. Thrift (Eds.), Writing the rural: Five cultural geographies, (pp. 149-190). London: Chapman.

Colne, C. (2007). Moral qualities of experiential narratives. Journal of Curriculum Studies, 39, 11-34. http://dx.doi.org/10.1080/00220270600884277

Colne, C., \& Boone, M. (2008). Local heroes, narrative worlds and the imagination: The making of a moral curriculum through experiential narratives. Curriculum Inquiry, 38, 7-37. http://dx.doi.org/10.1111/j.1467-873X.2007.00396.x

Colne, C., \& deBeyer, M. (2009). Appraising the ethos of experiential narratives: Key aspects of a methodological challenge. Educational Theory, 59, 41-65. http://dx.doi.org/10.1111/j.1741-5446.2009.00306.x

Connolly, M., \& Clandinin, D. J. (1990). Stories of experience and narrative inquiry. Educational Researcher, 19, 2-14. http://dx.doi.org/10.3102/0013189X019005002

Delanty, G. (2001). Challenging knowledge: The university in the knowledge society. Buckingham: Society for Research into Higher Education and Open University Press.

Denzin, N. H., \& Lincoln, Y. S. (2000). The Handbook of Qualitative Research. Thousand Oaks, CA: Sage.

Elliott-Johns, S. E. (2011). Reclaiming a writing voice as a new teacher educator: SoTL as portal. International Journal for the Scholarship of Teaching and Learning, 5, 9.

Ellis, C., Adams, T., \& Bochner, E. (2011). Autoethnography: an over- 
view. Forum: Qualitative Social Research, 12, Article 10.

Estrella, M., Blauert, J., \& Campilan, D. (2000). Learning from change: Issues and experiences in participatory monitoring and evaluation. Ottawa: IDRC Books.

Estrella, M. B., \& Gaventa, J. (1998). Who counts reality? Participatory monitoring and evaluation: A literature review. Brighton: Institute of Development Studies, University of Sussex.

Fry, H., Ketteridge, S., \& Marshall, S. (2003). A handbook for teaching and learning in higher education: Enhancing academic practice. London: Routledge Falmer.

Geertz, C. (2000). Available light: Anthropological reflections on philosophical topics. Princeton: Princeton University Press.

Heiftetz, R., \& Linsky, M. (2002). Leadership on the line: Staying alive through the dangers of leading. Boston: Harvard Business School Press.

Jackson, N. (2005). Making higher education a more creative place. Journal for the Enhancement of Learning and Teaching, 2, 14-25.

Lea, M. R., \& Stierer, B. (2009). Lecturers' everyday writing as professional practice in the university as workplace: New insights into academic identities. Studies in Higher Education, 34, 417-428. http://dx.doi.org/10.1080/03075070902771952

Manathunga, C., Peseta, T., \& McCormack, C. (2010). Supervisor development through creative approaches to writing. International Journal for Academic Development, 15, 33-46. http://dx.doi.org/10.1080/13601440903529893

Marcus, L. (1998). Auto/biographical discourses: Criticism, theory, practice. Manchester: Manchester University Press,

Miller, C. M. L., \& Parlett, M. (1976). Cue consciousness. In M. Hammersley, \& P. Woods (Eds). The process of schooling (pp. 143-150). London: Routledge and Kegan Paul.

Nowotny, H., Scott, P., \& Gibbons, M. (2001). Re-thinking science:
Knowledge and the public in an age of uncertainty. Cambridge: Polity Press.

Parry, S. (2007). Disciplines and doctorates. Dordrecht: Springer.

Parry, S. (1998). Disciplinary discourse in doctoral theses. Higher Education, 36, 273-299. http://dx.doi.org/10.1023/A:1003216613001

Radi, D. A., Hildebrandt, P., \& Martin, J. (2008). First experiences of four Ph.D. students in collaborative narrative inquiry research: The Artsmarts Research Project. http://www.artssmarts.ca

Roberts, B. (2002). Biographical research. Buckingham: Open University Press.

Searby, L. J., \& Tripses, J. S. (2011). Going to the balcony: Two professors reflect and examine their pedagogy. International Journal for the Scholarship of Teaching and Learning, 5, 11.

Schön, D. (1987). Educating the reflective practitioner. San Francisco: Jossey-Bass.

Silverman, D. (1997). Qualitative research: Theory, method and practice. London: Sage.

Swales, J., \& Najjar, H. (1987). The writing of research article introductions. Written Communication, 4, 175-191. http://dx.doi.org/10.1177/0741088387004002004

Taylor, L. (2010). Editorial: Practising in context: Embracing the diversity of academic development practice and scholarship. International Journal for Academic Development, 15, 1-3. http://dx.doi.org/10.1080/13601440903529802

Trahar, S. (2009). Beyond the story itself: Narrative inquiry and autoethnography in intercultural research in higher education. Forum: Qualitative Social Research, 10, 20.

Vygotskii, L. S. (1935). Dinamika umstvennogo razvitiia shkol'nika v sviazi s obucheniem. In Umstvennoe razvitie detei v protsesse obucheniia (pp. 33-52). Moscow-Leningrad: Gosuchpedgiz. 